\title{
Affecting Factors of HIV Counseling and Test in Pregnant Mothers: Narrative Review
}

\author{
Anggela Pradiva Putri ${ }^{1}$ \\ \{anggela.pradiva@gmail.com ${ }^{1}$ \} \\ Department of Reproductive Health, Faculty of Public Health, Universitas Andalas, \\ Padang, West Sumatera, 25128, Indonesia
}

\begin{abstract}
World Health Organization (WHO) data show that by the end of 2015, around 36.7 million people had HIV. In Indonesia, the HIV prevalence from 2011-2016 is increasing every year. In 2011 , it was $0.38 \%$ to $0.5 \%$ in 2016 . In the world, every day, around 2000 children aged 15 years and under are infected with HIV due to transmission from mother to baby. The study was conducted with a narrative review, which is a study of 5 studies conducted quantitatively. From various literature found that several influential factors are Antenatal Care (ANC) with $R R=2.64$, living in urban $R R=2.85$, knowledge about HIV RR $=4.3$, support of partners $\mathrm{RR}=9.19$, and knowledge of PMTCT (Prevention of Mother of Child Transmission) $\mathrm{RR}=3.27$. HIV testing is influenced by various factors, including knowledge, husband and family support, ANC examination, and the age of pregnant women.
\end{abstract}

Keywords: HIV / AIDS, HIV testing, Pregnant mother, VCT

\section{Introduction}

HIV or Human Immunodeficiency Virus is a type of virus that attacks/infects white blood cells that cause a decrease in human immunity. AIDS or Acquired Immune Deficiency Syndrome is a group of diseases that arise due to decreased immunity caused by HIV. As a result of decreased immunity, the person is very susceptible to various infectious diseases (opportunistic infections), which are often fatal. People living with HIV need antiretroviral (ARV) treatment to reduce the amount of HIV in the body, so it does not enter the AIDS stage, and people with AIDS also need ARVs to prevent opportunistic infections by its complications $[1]$.

WHO (World Health Organization) data show that by the end of 2015, around 36.7 million people had HIV. As many as 18.2 million people in mid-2016 received ARV treatment in the world (WHO, 2016). Data from UNAIDS (United Nations Program on HIV / AIDS) shows that in Asia Pacific, there was an increase in HIV cases from 2010 of 4.7 million to 5.1 million. In Indonesia alone, the HIV prevalence from 2011-2016 is increasing every year. In 2011 it was $0.38 \%$ to $0.5 \%$ in 2016 .

Currently, housewives are one of the most vulnerable groups to HIV / AIDS and are receiving serious attention from WHO. In the world, every day, around 2000 children aged 15 years and under are infected with HIV due to transmission from mother to baby. Data in the world in 2015 showed 8 out of 10 pregnant women living with HIV and 1.1 million women receiving ARV treatment. For in Indonesia, the estimated HIV prevalence in pregnant women from $2011-2016$ tended to increase from $0.34 \%$ to $0.49 \%$.

Seeing the high prevalence above, the current problem of HIV / AIDS is not just a health problem from infectious diseases but has become a very broad public health problem. Therefore, handling is not 
only from a medical perspective but also from a psychosocial basis based on a public health approach through primary, secondary, and tertiary prevention efforts. One such effort is early detection to find out whether someone has been infected with HIV or not through voluntary HIV / AIDS counseling and testing, not forced or compulsory. Identifying HIV status earlier will help the patient to get services related to prevention, care, support, and treatment, so voluntary HIV / AIDS counseling and testing is the entry point for all of these services.

Based on the Regulation of the Minister of Health No. 21/2013, Article 17 states that for the examination of pregnant women who check their pregnancy, health promotion and prevention of HIV transmission must be carried out. Prevention of HIV transmission in question is through testing HIV diagnostics with tests and counseling.

Voluntary Counseling and Testing, known as Voluntary Counseling and Testing (VCT) is one of the public health strategies and as an entry point for all sustainable HIV / AIDS health services. VCT services are performed according to the needs of patients, both HIV positive and negative. These services include counseling, support, access to supportive therapy, treatment for ophthalmic infections, and ARVs. VCT is done by professionals who are trained and trained so that they can dig up information from patients and can reduce risky behavior and prevent the spread of infection to others. HIV testing is done voluntarily without coercion and pressure, as soon as the patient understands the benefits, consequences, and risks.

The narrative review of some of these studies aims to describe the factors that influence HIV counseling and testing in pregnant women.

\section{Method}

The study was conducted with a narrative review. The source comes from the literature obtained from the University of Indonesia's online library database.

Inclusion criteria are journals that discuss funding HIV testing in women and pregnant women, which are restricted from 2007-2017. Analysis and presentation of results, discussion, and formulation of conclusions are made. However, this method was not conducted in a meta-analysis because the articles examined included quantitative research.

\section{Figure1.Research Flow}

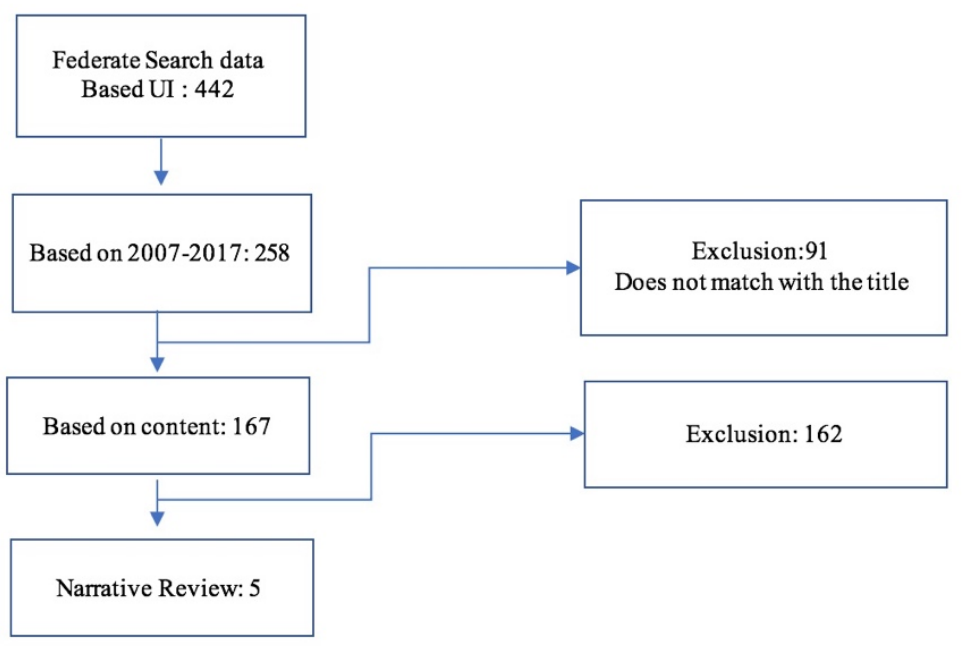


Study Design. Three articles will be conducted on a narrative review using a crosssectional design, one article with a systematic review, and one article with a qualitative design.

Table of Findings. This table consists of the findings of articles that are relevant for a systematic narrative review, including author, year of publication, research location, subject or exposure, research questions, research study design, samples, results /conclusions.

Table 1. Table of Findings

\begin{tabular}{|c|c|c|c|c|c|}
\hline $\begin{array}{l}\text { Authors, Years, } \\
\text { study, location }\end{array}$ & $\begin{array}{l}\text { Subject } \\
\text { /Exposure }\end{array}$ & $\begin{array}{l}\text { Study } \\
\text { question } \\
\text { Ple } \\
\end{array}$ & $\begin{array}{l}\text { Study } \\
\text { design }\end{array}$ & Sampling & $\begin{array}{l}\text { Result/ } \\
\text { conclusion }\end{array}$ \\
\hline $\begin{array}{l}\text { Malaju\&Alene, } \\
\text { 2012, Ethiopia }\end{array}$ & VCT reception & $\begin{array}{l}\text { What } \\
\text { influences } \\
\text { the reception } \\
\text { of VCT }\end{array}$ & $\begin{array}{l}\text { Cross- } \\
\text { Sectional }\end{array}$ & $\mathrm{n}=400$ & $\begin{array}{l}\text { Utilization of } \\
\text { VCT was highest } \\
\text { at ANC }\end{array}$ \\
\hline $\begin{array}{l}\text { Ghoma- } \\
\text { Linguissi, } 2015, \\
\text { Republic } \\
\text { Congo }\end{array}$ & HIV Testing & $\begin{array}{l}\text { What factors } \\
\text { influence } \\
\text { HIV testing }\end{array}$ & $\begin{array}{l}\text { Cross- } \\
\text { Sectional }\end{array}$ & $\mathrm{n}=136$ & $\begin{array}{l}\text { Knowledge } \\
\text { about HIV is } \\
\text { crucial to } \\
\text { increasing HIV } \\
\text { testing }\end{array}$ \\
\hline $\begin{array}{l}\text { Iwelunmor, et al., } \\
\text { 2014, Nigeria }\end{array}$ & PMTCT & $\begin{array}{l}\text { What factors } \\
\text { influence } \\
\text { PMTCT and } \\
\text { HIV-related } \\
\text { programs }\end{array}$ & PEN-3 & $\begin{array}{l}42 \\
\text { Articles }\end{array}$ & $\begin{array}{l}\text { Family support, } \\
\text { community } \\
\text { culture needs to } \\
\text { be optimized to } \\
\text { eliminate HIV } \\
\text { transmission from } \\
\text { mother to child }\end{array}$ \\
\hline $\begin{array}{l}\text { Peltzer\&Mlambo, } \\
2013, \quad \text { South } \\
\text { Africa }\end{array}$ & $\begin{array}{l}\text { HIV risk } \\
\text { PMTCT }\end{array}$ & $\begin{array}{l}\text { Knowing the } \\
\text { risk of HIV } \\
\text { and related } \\
\text { factors }\end{array}$ & $\begin{array}{l}\text { Cross- } \\
\text { Sectional }\end{array}$ & $\mathrm{n}=1.502$ & $\begin{array}{l}\text { The highest risk } \\
\text { of HIV during } \\
\text { pregnancy }\end{array}$ \\
\hline $\begin{array}{l}\text { Hardon, A. P, et } \\
\text { al,2009, } \\
\text { Vietnam\& }\end{array}$ & & $\begin{array}{l}\text { related to } \\
\text { HIV } \\
\text { Find out }\end{array}$ & & $\begin{array}{l}=113 \\
\text { health } \\
\text { workers }\end{array}$ & \\
\hline Indonesia & & $\begin{array}{l}\text { how PMTCT } \\
\text { is in } \\
\text { Vietnam and } \\
\text { Indonesia }\end{array}$ & Qualitative & $=72$ & $\begin{array}{l}\text { The highest risk } \\
\text { of HIV during } \\
\text { pregnancy The } \\
\text { success of } \\
\text { contextual, } \\
\text { gender-specific } \\
\text { PMTCT } \\
\text { transmission HIV } \\
\text { pathway, as well } \\
\text { as local } \\
\text { opportunities for } \\
\text { continued care } \\
\text { and social } \\
\text { support. }\end{array}$ \\
\hline
\end{tabular}




\section{Result}

The results of Malaju \& Alene's study (2012) reported that the acceptance of pregnant women with HIV testing and counseling relates to several factors, namely Antenatal Care (ANC) with $R R=2.64$, living in urban areas $R R=2.85$, knowledge about HIV $R R=4.3$, support of RR partners $=8.19$, and knowledge about PMTCT (Prevention of Mother to Child Transmission) $R R=3.27$. The Ghoma-Linguissi study (2015) showed that pregnant mothers' knowledge of HIV (RR $=5.01)$ was the most influential factor for acceptance for HIV testing.

Peltzer \& Mlambo research (2013) shows factors of knowledge, male involvement, and positive HIV status influence the participation of HIV testing. Research Iwelunmor, et al. (2014) explain the perception, availability, and affordability of PMTCT are factors that influence HIV testing for pregnant women. Hardon's research (2009) shows the success of PMTCT is influenced by ANC participation, attitudes of health workers, knowledge of pregnant women, and husband support.

Tabel 2. Factors affecting HIV testing

\begin{tabular}{|c|c|c|c|c|c|c|}
\hline \multirow[t]{2}{*}{ No } & \multirow{2}{*}{$\begin{array}{l}\text { Authors, Years, } \\
\text { study, location }\end{array}$} & \multirow[b]{2}{*}{ ANC } & \multicolumn{4}{|c|}{ Factors affecting HIV testing } \\
\hline & & & Residence & Knowledge & $\begin{array}{c}\text { Spouse/family } \\
\text { support }\end{array}$ & Age \\
\hline 1 & $\begin{array}{l}\text { Malaju\&Alene, } \\
\text { 2012, Ethiopia }\end{array}$ & $\sqrt{ }$ & $\sqrt{ }$ & $\sqrt{ }$ & $\sqrt{ }$ & NA \\
\hline 2 & $\begin{array}{l}\text { Ghoma- } \\
\text { Linguissi,2015, } \\
\text { Republic of } \\
\text { Congo }\end{array}$ & NA & - & $\sqrt{ }$ & & - \\
\hline 3 & $\begin{array}{l}\text { Iwelunmor, et,al, } \\
\text { 2014, Nigeria }\end{array}$ & - & - & $\sqrt{ }$ & $\sqrt{ }$ & $\sqrt{ }$ \\
\hline 4 & $\begin{array}{l}\text { Peltzer\&Mlambo, } \\
\text { 2013, South } \\
\text { Africa }\end{array}$ & - & - & $\sqrt{ }$ & $\sqrt{ }$ & - \\
\hline 5 & $\begin{array}{l}\text { Hardon, A. P, , } \\
\text { et,al,2009, } \\
\text { Vietnam\& } \\
\text { Indonesia }\end{array}$ & $\sqrt{ }$ & - & $\sqrt{ }$ & $\sqrt{ }$ & - \\
\hline
\end{tabular}

NA: No Assosiation

- : not researched

\section{Discussion}

HIV / AIDS can be prevented through delaying age for first time sex, increasing condom use, reducing to change sexual partners, promoting health promotion of sexually transmitted infections (STI), increasing access to voluntary HIV counseling and testing, and reducing habits that can increase risk affected by HIV such as the use of illegal drugs, and the use of illegal drugs using syringes.

The HIV epidemic in Indonesia has been going on for 25 years, and since 2000 has been grouped in several high-risk sub-populations, namely injecting drug users (IDUs), Female Sex 
Workers (FSW), MSM (Men Like Men), and transgenders. The estimation results of the 2012 vulnerable population are estimated to have 13.8 million people prone to HIV infection with a total of 6 million people and their partners almost 5 million people, and unwittingly housewives are a group who are also at risk for contracting HIV.

Enforcement of HIV status in pregnant women as early as possible is very important for the prevention of HIV transmission from mother to baby. Ghoma-Linguissi's research results (2015) showed that knowledge is a factor that influences the acceptance of pregnant women towards HIV testing. Mothers of primary or secondary education level who know about HIV can receive HIV tests five times more than mothers who do not get an education. The same thing was also obtained from Anggraini's research (2014) that respondents with good knowledge were more likely to take an HIV test compared to respondents with less knowledge.

Knowledge is included in predisposing factors that cause behavior in a person (Notoadmodjo, 2010). In HIV testing, knowledge is a key factor for pregnant women to want to do an HIV test. The determiner of information about HIV / AIDS by health promotion can affect the increase in HIV testing of pregnant women.

Another factor influencing HIV testing in pregnant women is husband support. Husband's support is considered important because there is still a patriarchal culture, that the husband is the party that makes decisions in the household. Research Iwelunmor, et al. (2014) states that the support of husband and family for HIV testing is very important because the husband can provide optimal access to pregnant women. Hardon's research (2009) also shows that partner/husband support has an impact on PMTCT. The form of husband involvement is by being aware of the risk of HIV so that it can be prevented from being transmitted to his wife and children. This result is in line with the study of PS, et al. (2012) that respondents with good husband support do more HIV tests than those who do not get support, and there is a relationship between husband support with test behavior.

Research Malaju \& Alene (2012) states that ANC has a relationship with HIV testing. The results of this study stated that the greater the number of ANC visits, the greater the acceptance of pregnant women with HIV testing. This is because HIV testing that takes place at the time of ANC can provide better information about HIV so that acceptance and willingness to test for HIV also increases. HIV information can be well received if midwives provide good support. Hardon Research (2009), ANC also influences maternal involvement in HIV testing. In addition, the attitude of health workers in the service area also influences HIV testing, where health workers who lack understanding of the concept of counseling tend to do nothing when the patient is diagnosed with HIV + so that the patient feels confused about continuing HIV service.

It is in line with research PS, et al. (2012), which states that respondents with good midwife support, more testing for HIV. Research Malaju \& Alene (2012) also states that there is no relationship between the age of pregnant women with HIV testing. This is due to the possibility of pregnant women, both young and adults having their own views on HIV risk and understanding of the importance of HIV testing. This is in line with research PS, et al. (2012), which states that there is no statistical relationship between the age of pregnant women with the behavior of pregnant women for HIV testing. Even though age has no relationship with HIV test behavior, older respondents have more HIV tests than younger respondents. 


\section{Conclusion}

HIV counseling and testing need to be utilized as well as possible by the community, including vulnerable parties, one of which is pregnant women. Therefore the things that need to be done:

1. Increase the knowledge and understanding of pregnant women about the importance of HIV testing and its benefits through health promotion

2. Increasing husband and family support for pregnant women for HIV testing

3. Implementation of a good ANC as a forum for pregnant women to carry out HIV testing and support of midwives who guide pregnant women.

\section{References}

[1] Infodatin.2014.Situasi dan Analisis HIV AIDS.Jakarta: Kementerian Kesehatan RI

[2] Joint United Nations Programme on HIV/AIDS (UNAIDS), \& Joint United Nations Programme on HIV/AIDS (UNAIDS). (2016). Global AIDS update 2016. Geneva, Switzerland.

[3] Notoatmodjo S. 2010. Promosi Kesehatan Teori dan Aplikasi. Jakarta: Rineke Cipta

[4] Kementerian Kesehatan RI. 2013. Peraturan Menteri Kesehatan Nomor 21 Tahun 2013. Jakarta

[5] Departemen Kesehatan RI. 2006. Pedoman Pelayanan Konseling dan Testing HIV/AIDS secara Sukarela. Jakarta

[6] Mishra, R.C. 2009 .HIV/AIDS Education. New Delhi: APH Publishing Corporation

[7] PS, T. L., Shaluhiyah, Z., \& Suryoputro, A. (2012). Perilaku Ibu Hamil untuk Tes HIV di Kelurahan Bandarharjo dan Tanjung Mas Kota Semarang. Jurnal Promosi Kesehatan Indonesia, 7(2), 153-164.

[8] Anggrarini, I. (2014). Faktor-Faktor Yang Mempengaruhi Perilaku Pemeriksaan VCT Pada Ibu Hamil Di Wilayah Kerja Puskesmas Ii Melaya Kabupaten Jembrana Provinsi Bali. Ungaran: Prodi Studi Diploma Iv Kebidanan Stikes Ngudi Waluyo.

[9] Iwelunmor, J., Ezeanolue, E. E., Airhihenbuwa, C. O., Obiefune, M. C., Ezeanolue, C. O., \& Ogedegbe, G. G. (2014). Socio-cultural factors influencing the prevention of mother-to child transmission of HIV in nigeria: A synthesis of the literature. BMC Public Health, 14, 771. doi:http://dx.doi.org/10.1186/1471-2458-14-771

[10] Malaju, M. T., \& Alene, G. D. (2012). Assessment of utilization of provider-initiated HIV testing and counseling as an intervention for prevention of mother to child transmission of HIV and associated factors among pregnant women in gondar town, north west ethiopia. BMC Public Health, 12, 226. doi:http://dx.doi.org/10.1186/1471-2458-12-226

[11] Hardon, A. P., Oosterhoff, P., Imelda, J. D., Anh, N. T., \& Hidayana, I. (2009). Preventing mother to-child transmission of HIV in Vietnam and Indonesia: diverging care dynamics. Social science \& medicine, 69(6), 838-845. 